\title{
Large airway ventilatory functions in female patients of rheumatoid arthritis with methotrexate therapy- is there any change?
}

\author{
Fatema Yasmin ${ }^{1}$, Shelina Begum ${ }^{2}$
}

\begin{abstract}
Background: Methotrexate (MTX) is widely used in the treatment of Rheumatoid arthritis (RA) as first line disease modifying anti-rheumatoid drug. Low dose MTX may reduce lung function status in RA patients. Objective: To observe the changes in large airway ventilatory variables in RA patients after MTX therapy. Methods: For this prospective observational study, 24 female RA patients of age ranges between 15 to 65 years were selected from the Out-Patient Department of Rheumatology, Bangabandhu Sheikh Mujib Medical University, Dhaka. Age and BMI matched 24 apparently healthy females were also selected Control. To assess the large airway ventilatory function, $\mathrm{FVC}, \mathrm{FEV}_{1}, \mathrm{FEV}_{1} /$ FVC\% and PEFR of all subjects were measured with a portable digital Spirometer, PONY FX (Cosmed, Italy) at Day 0. In addition, all these variables were again measured in the RA patients after 180 days of MTX therapy. For statistical analysis, independent sample $t$ test and paired sample $t$ test were performed. Results: All the study variables (except $\mathrm{FEV}_{1} / \mathrm{FVC} \%$ ) were significantly $(\mathrm{p}<0.001)$ lower in RA groups at day 0 as well as at day 180, compared to healthy controls. Again all these variables were almost similar in the RA patients at day 180 when compared to those of day 0 . Conclusion: Large airway ventilatory function deteriorated in RA patients, which may not be recovered by six months methotraxate therapy.
\end{abstract}

Key words: Rheumatoid arthritis, Methotrexate, $\mathrm{FVC}_{1} \mathrm{FEV}_{1}, \mathrm{FEV}_{1} / \mathrm{FVC} \%$, PEFR.

J Bangladesh Soc Physiol. 2018, June; 13(1): 35-40 For Authors Affiliation, see end of text.

http://www.banglajol.info/index.php/JBSP DOI: http://dx.doi.org/10.3329/jbsp.v13i1.37847

\section{Introduction}

$\mathbf{R}$ heumatoid arthritis (RA) is the most common persistent autoimmune inflammatory connective tissues disorder throughout the world. Global prevalence of RA is approximately $1 \%$ and in Bangladesh is about $1.6 \%{ }^{1-2}$. Typical presentations are joint pain, swelling and stiffness, affecting small joints of hands, feet and wrist associated with systemic disorder and extra-articular features ${ }^{3}$. The

Received 11 January 2018; Accepted 03 April 2018

J Bangladesh Soc Physiol. 2018, June; 13(1): 35-40 etiology of rheumatoid arthritis is unknown but linked with genetic and environmental factors which are implicated in the pathogenesis of the disease.

In RA, pulmonary involvement is the second common extra-articular manifestation and 25\% to $70 \%$ patients with RA presents with pulmonary abnormalities $^{4-5}$. About $22 \%$ of the affected RA patients died due to respiratory complication ranging from pleurisy, pulmonary nodules, pulmonary vasculitis, interstitial pulmonary fibrosis, airway disease and pleural effusion ${ }^{6}$ to 
fibrosed lung followed by impaired lung function ${ }^{6-8}$. Forty $(40 \%)$ percent of the RA patients suffers with interstitial lung disease and subclinical alveolitis ${ }^{9-11}$. Small airway involvement was found in $38 \%$ of RA patients which appears as the commonest form of pulmonary involvement of rheumatoid lung disease ${ }^{11}$. About $85 \%$ of RA patients suffer with thickened bronchial wall. Bronchial dilatation is present in $62 \%$ patients with RA. Moreover, $14 \%$ patients with RA are affected with small airway obstruction $^{12-14}$.

For the treatment of RA, methotraxate (MTX, N10 methyl aminopterin, a folate analogue) is an ideal agent, which halts the progression of bony erosions, thereby preventing joint deformity and morbidity. ${ }^{15-18}$

Pulmonary complications occurred in $7.6 \%$ RA patients treated with low dose MTX ${ }^{19-21}$. It is also reported that 1 to $7 \%$ patients treated with MTXmight develop pulmonary toxicity within first year of treatment ${ }^{22-23}$. Approximately $17.5 \%$ RA patients treated with MTX those who develop lung disease might die from this complication ${ }^{22}$.

Significantly lower mean percentages of predicted value of FVC in RA patients without ${ }^{5-}$ 6,24-25 and after low dose MTX therapy have been reported $^{26-27}$. On the other hand, non-significant decrease in FVC value after MTX treatment in patients with RA has also been published ${ }^{28-29}$.

Similar pattern of change involving $\mathrm{FEV}_{1}$ was also reported in RA without and after MTX treatent. $8,25-30$.

In addition, similar data in $\mathrm{FEV}_{1} / \mathrm{FVC} \%$ in $\mathrm{RA}$ before and after MTX treatment has been published ${ }^{25,30-31}$ but Khadadah et al. ${ }^{27}$ reported significant increment in $\mathrm{FEV}_{1} / \mathrm{FVC}$ ratio in MTX treated RA patients compared to baseline. Along with $\mathrm{FVC}, \mathrm{FEV}_{1}, \mathrm{FEV}_{1} / \mathrm{FVC} \%$, PEFR (indicator of respiratory muscle strength) was also shown to be lowered in patients of $\mathrm{RA}^{8}$.

Because of the inconsistent outcomes of different studies, this study has been designed to investigate the changes of spirometric variables in female RA patients and also to compare these data after six months MTX therapy in same patients.

\section{Methods}

This prospective observational study was carried out in the Department of Physiology, Bangabandhu Sheikh Mujib Medical University (BSMMU), Dhaka, from March 2017 to February 2018. The protocol of this study was approved by the Institutional Review Board, BSMMU. For this, 24 female diagnosed RA patients by the rheumatologist (American College of Rheumatology (ACR) 2010 criteria $^{32[40]}$ ) of 15 to 65 year were selected from the Out Patient Department (OPD) of Rheumatology, BSMMU. Age and BMI matched 24 apparently healthy females were further selected through personal contact (Control). Subjects with history of smoking, bronchial asthma, COPD, pulmonary fibrosis, pneumonia, tuberculosis, pneumothorax, pneumoconiosis, extrinsic allergic alveolities, ischemic heart disease, hepatic disease, kidney disease, musculoskeletal abnormality, collagen vascular disease (dermatomyositis, psoriatic arthritis, SLE) in addition to current pregnancy or planning to pregnancy orcurrent lactation, were excluded from study. After selection, the objectives, nature, purpose were explained in detail to the subjects and informed written consent was taken from all subjects. Detailed family history, medical history and thorough physical examination of each patient were done and documented. Large airway ventilatory variables $\left(\mathrm{FVC}, \mathrm{FEV}_{1}, \mathrm{FEV}_{1} / \mathrm{FVC} \%\right.$, PEFR) were measured with a portable digital Spirometer, PONY FX (Cosmed, Italy), at baseline of all subjects (at day 0 ) and also after completion of six months MTX therapy (at day 180). Data were expressed as mean $\pm \mathrm{SE}$ of percentage of predicted value. For statistical analysis, independent sample $t$ test and paired sample $t$ test were performed by using SPSS(version 20). In the interpretation of results, $p$ value of $\leq 0.05$ was considered as statistically significant. 


\section{Results}

In this study, both the control and RA patients were comparable, in respect of age and BMI, as their differences were statistically non significant (Figure 1). At base line, the mean percentage predicted values of FVC (Figure 2A), $\mathrm{FEV}_{1}$ (Figure 2B), PEFR (Figure 2D) were significantly (pd"0.001) lower and $\mathrm{FEV}_{1} / \mathrm{FVC} \%$ (Figure $2 \mathrm{C}$ ) was significantly (p£0.001) higher in RA patients at Day 0 before MTX therapy, compared to healthy control. In addition, $\mathrm{FVC}$ (Figure 2A), $\mathrm{FEV}_{1} /$ $\mathrm{FVC}$ \% (Figure 2C), PEFR (Figure 2D) were slightly increased and $\mathrm{FEV}_{1}$ (Figure 2B) was slightly decreased at day 180 (after six months MTX therapy)in comparison to those of day 0 but the differences were statistically non
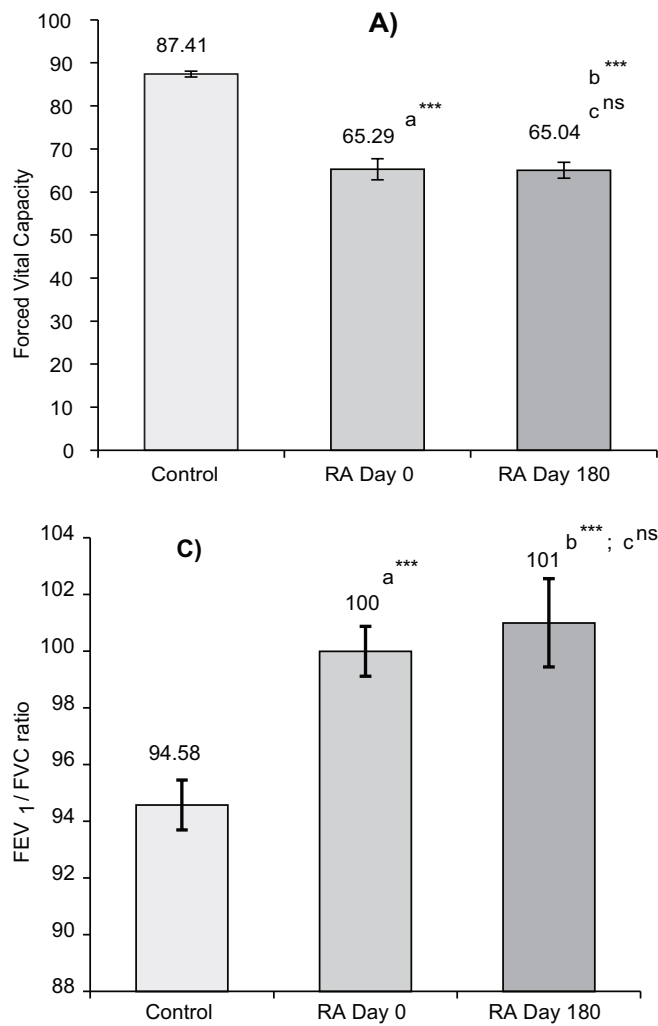

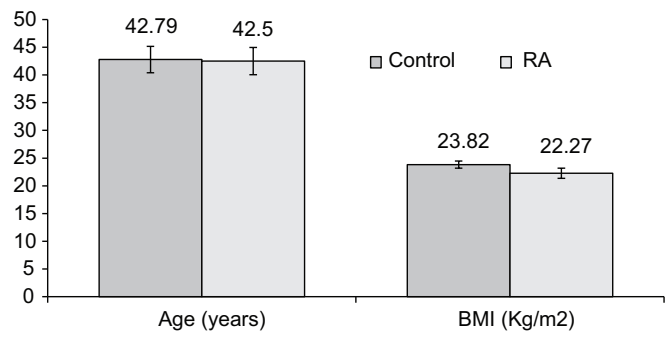

Figure 1: Baseline characteristics of all subjects $(\mathrm{n}=48)$

Data were expressed as mean \pm SE. Statistical analysis was done by Independent sample $t$ test. BMI=Body Mass Index; RA=Rheumatoid arthritis; ns=non significant in Control vs RA
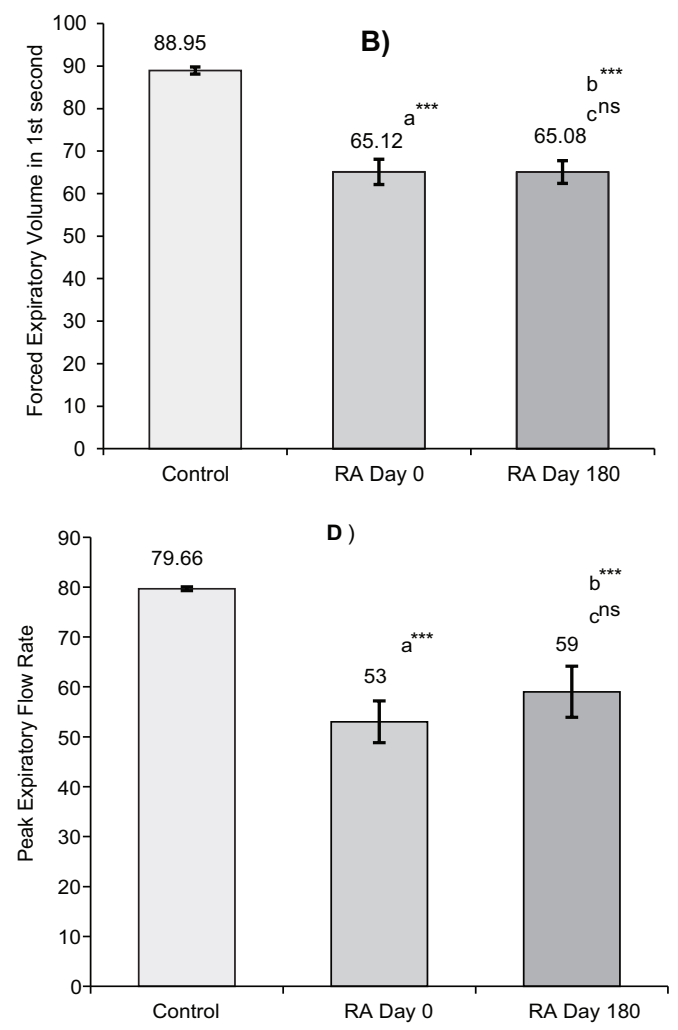

Figure 2: Large airway ventilatory variables in all subjects $(\mathrm{n}=48)$

Data were expressed as mean $\pm S E$ of percentage of predicted values of forced vital capacity (A), forced expiratory volume in $1^{\text {st }}$ second (B), FEV1/FVC ratio (C) and peak expiratory flow rate (D). Statistical analysis was done by independent sample $t$ test ( $a=$ control vs RA at day $0 ; b=$ control vs RA at day 180 ) and Student's paired t test (c=RA at day 0 vs RA at day 180). ${ }^{* * *}=$ significant (pd"0.001); ns=non significant; RA=Rheumatoid arthritis; day $0=$ before methotraxate therapy; day $180=$ after 6 months of methotraxate therapy

J Bangladesh Soc Physiol. 2018, June; 13(1):35-40 


\section{Discussion}

In the present study, we found significantly lowered FVC, FEV ${ }_{1}$ and PEFR in RA patients at baseline (before MTX therapy) than those of control group. Similar findings were observed by several investigators $5,8,25,30$. The cause of our finding might be due to movement limitation of chest cage, because of synovial joint affection (specially, costovertebral and costochondral) ${ }^{33-}$ 34 or respiratory muscle weakness ${ }^{13,33-35[43]}$ or inflammatory change in the bronchi ${ }^{13,29,33-34}$ in RA. We also found significantly higher $\mathrm{FEV}_{1} /$ $\mathrm{FVC} \%$ at baseline in our RA patients than those of healthy control. Similar finding was observed by several investigators ${ }^{25,30}$. This result suggests restrictive pattern of lung function impairment, which might be due to fibrotic change of lung parenchyma by augmentation of parenchymal inflammation through protein citrullination ${ }^{29,36-}$

${ }^{37}$ or differentiation and proliferation of fibroblast in lung parenchyma along with increased activity of matrix metalloproteinase ${ }^{13,36-37}$ in this morbid disorder.

Again, all of the large airway function variables (FVC, $\mathrm{FEV}_{1}, \mathrm{FEV}_{1} / \mathrm{FVC} \%$, PEFR) of our RA patients were almost similar after six months of MTX therapy to those of their baseline, as their differences were statistically non-significant. These observations were in agreement with findings of other investigators of different countries $^{8,27,29,38}$. Our findings suggest no effect of MTX on improvement of ventilatory function (in spite of decrement of RA symptoms) of our RA patients, which might be due to decrement of alveolar epithelial cell and increment of myelofibroblasts proliferation by MTX $^{23,39}$ causing altered physiological and mechanical function of lung and subsequently increment of airway resistance $23,27,40$.

\section{Conclusion}

From our study it is concluded that, large airway ventilatory functions deteriorate in RA patients, which may not be improved with six months' traditional disease modifying anti rheumatoid drug - methotraxate. Study on RA patients with MTX therapy of longer duration is further recommended for inferential outcome.

\section{Conflict of interest None.}

Authors affiliations:

1. *Fatema Yasmin, Consultant, Ingenious Pulmo-Fit, Shaymoli, Dhaka, Bangladesh. Email: ms.yasminbm14@gmail.com

2. Shelina Begum, Professor, Department of Physiology, Bangabandhu Sheikh Mujib Medical University (BSMMU), Dhaka, Bangladesh. Email:shelina1982@gmail.com

* for correspondence

\section{References}

1. Fuld JP, Johnson MK, Cotton MM, Carter R, Watkin SW, Capell HA, Stevenson RD. A longitudinal study of lung function in nonsmoking patients with rheumatoid arthritis. CHEST. 2003;124(4): 12241231 .

2. Ahmed S, Haq S, Al-qadir A, Rahman MM, Paul S. Survey on prevalence of rheumatic disorders in Bangladeshi adults. Ann Rheum Dis. 2017;76(2): 1044-1045.

3. Ralston HS, Mcinnes BI. Davidson2 s Principles and Practice of Medicine. $22^{\text {nd }}$ ed. China: Elsevier. 2014; 25:1096-1103.

4. Anaya JM, Diethelm L, Ortiz LA, Gutirrerz M, Citera G, Welsh RA. Pulmonary involvement in rheumatoid arthritis. Semin Arthritis Rheum. 1995 Feb; 24: 242-254.

5. Hassan WU, Keaney NP, Holland CD, Kelly CA. Bronchial reactivity and airflow obstruction in rheumatoid arthritis. Ann Rheum Dis.1995; 53: 511-514.

6. Kanat F, Levendoglu F, Teke T. Radiological and functional assessment of pulmonary involvement in the rheumatoid arthritis patients. Rheumatol Int. 2007; 27: 459-466. DOI: $10.1007 / \mathrm{s} 00296-$ 006-0234-0.

7. Tanoue LT. Pulmonary manifestations of rheumatoid arthritis. Clin Chest Med. 1998; 19:667-685.

8. Bilgici A, Ulusoy H, Kuru O, Celenk C, Unsal M, Danaci M. Pulmonary involvement in rheumatoid arthritis. Rheumatol Int. 2005; 25: 429-435. DOI: 10.1007/s00296-004-0472-y.

9. Frank ST, John GW, Hakleroad LE, Fitch RF. Pulmonary Dysfunction in Rheumatoid Disease. CHEST.1973; 63: 27-35.

J Bangladesh Soc Physiol. 2018, June; 13(1): 35-40 
10. Perez T, Remy-Jardin M, Cortet B. Airways Involvement in Rheumatoid Arthritis. Am J Respir Crit Care Med. 1998;157: 1658-1665.

11. Popp W, Rauscher H, Ritschka L, Braun O, Scherak O, Kolarz G, Zwick H. Prediction of interstitial lung involvement in rheumatoid arthritis. The Value of clinical Data, Chest roentgenogram, lung function and serologic parameters. CHEST. 1992;102 (2): 391-394.

12. Cortet B, Perez T, Roux N, Flipo RM, Duquesnoy B, Delcambre B, Remy-Jardin M. Pulmonary function tests and high resolution computed tomography of the lungs in patients with rheumatoid arthritis. Ann Rheum Dis. 1997; 56: 596-600.

13. Shaw M, Collins FB, Ho AL, Raghu G. Rheumatoid arthritis- associated lung disease. Eur Respir rev.2015; 24: 1-16. DOI: 10.1183/ 09059180.00008014 .

14. Tuomi T, Heliövaara M, Palosuo T, Aho K. Smoking, lung function and rheumatoid factors. Ann Rheum Dis. 1990; 49:753-756.

15. Bologna C, Viu P, Picot M-C, Jorgenssen C, Sany J. Long-term follow-up of 453 rheumatoid arthritis patients treated with Methotrexate: an open, retrospective observational study. Br J Rheum. 1997; 36: 535-540.

16. Michaels RM, Nashal DJ, Leonard A, Sliwinksi JA, Derbes JS. Weekly intravenous methotrexate in treatment of rheumatoid arthritis. Arthritis Rheum. 1982; 25:339-341.

17. Acuthan A, Dham SK. Long term trial of low dose Methotrexate in Rheumatoid Arthritis. IJPMR.1993;6(2): 15-20.

18. Hamdy H, McKendry RJ, Mierins E, Liver JA. Low dose Methotrexate compared with azathioprine in Rheumatoid Arthritis. a twenty-four - week controlled clinical trial. Arthritis Rheum.1987 Apr; 30: 361-368.

19. Cannon GW, Ward JR, Clegg DO, Samuelson CO, Abbot TM. Acute lung disease associated with low dose pulse Methotrexate therapy in patients with rheumatoid arthritis. Arthritis Rheum.1983; 26:1269-74.

20. Hilliquin P, Renoux M, Perrot S, Puechal X, Menkes CJ. Occurrence of pulmonary complications during Methotrexate therapy in rheumatoid arthritis. $\mathrm{Br} \mathrm{J}$ Rheumatol. 1996; 35: 441-5.
21. Clearkin R, Corris PA, Thomas SHL. Methotrexate pneumonitis in a patient with rheumatoid arthritis. Postgrad Med J. 1997; 73:603-4.

22. Kremer JM, Alarcon GS, Weinblatt ME, Kaymakcian MV, Macaluso M, Cannon GW, Palmer WR, Sundy JS, William E, Alexander RW, Smith GJW, Axiotis CA. Clinical, laboratory, radiographic and histopathologic features of Methotrexateassociated lung injury in patients with rheumatoid arthritis. Arthritis Rheum. 1997 ; 40(10):182937.

23. Lateef O, Shakoor N, Balk RA. Methotrexate pulmonary toxicity. Expert Opin Drug Saf 2005; 4(4): 723-30.

24. Radoux V, Menard HA, Begin R, Decary F, Koopman WJ. Airways Disease in Rheumatoid Arthritis patients. Arthritis Rheum. 1987; 30(3): 249-256.

25. Kawassaki MA, Pereira SAD, Kay UF, Laurindo MML, Carvalho RRC, Kairalla. Pulmonary involvement in rheumatoid arthritis:evaluation by radiography and spirometry. J Bras Pneumol. 2015; 41(4): $331-42$. DOI: $10.1590 / \mathrm{S} 1806-$ 37132015000004518 .

26. Cottin V, Tébib J, Massonnet B, Souquet Pi-J, Bernard Je-P. Pulmonary function in patients receiving long-term low-dose methotrexate. CHEST. 1996; 109:933-8.

27. Khadadah ME, Jayakrisman B, Al-Gorair S, Almutairi M, Al-Muradni N, Onadeko B, Malaviya AN. Effects of Methotrexate on pulmonary function in patients with Rheumatoid arthritis: a prospective study. Rheumatol Int. 2002; 22: 2047. DOI: $10.1007 / \mathrm{s} 00296-002-0227-6$.

28. Dawson JK, Graham DR, Desmond J, Fewins HE, Lynch MP. Investigation of the chronic pulmonary effects of low-dose oral Methotrexate in patients with rheumatoid arthritis: a prospective study incorporating HRCT scanning and pulmonary function tests. Rheumatology (Oxford). 2002; 41(3): 262-7.

29. Attwa TE, Al-Shal N, Al- Mesry RM. Possible association of low dose Methotrexate therapy for rheumatoid arthritis with chronic pulmonary fibrosis. Egypt Rheumatol Rehab. 2003; 30(2): 311320.

30. Vergnenegre A, Pugnere N, Antonini MT, Arnaud M, Melloni B, Treves R, Bonnaud F. Airway obstruction and rheumatoid arthritis. Euro Resp J. 1997; 10: 1072-1078. DOI: 10.1183/ 09031936.97 .10051072 . 
31. Beyeler C, Jordi B, Gerber NJ, Imhof V. Pulmonary function in rheumatoid arthritis treated with low dose Methotrexate: a longitudinal study. Br J Rheumatol. 1996; 35:446-452.

32. Aletaha D, Neogi T, Silman AJ, Funovits J, Felson DT, Bingham CO 3rd, Birnbaum NS, Burmester GR, Bykerk VP, Cohen MD, Combe B, Costenbader KH, Dougados M, Emery P, Ferraccioli G, Hazes JM, Hobbs K, Huizinga TW, Kavanaugh A, Kay J, Kvien TK, Laing T, Mease P, Ménard HA, Moreland LW, Naden RL, Pincus T, Smolen JS, StanislawskaBiernat E, Symmons D, Tak PP, Upchurch KS, Vencovský J, Wolfe F, Hawker G.2010 Rheumatoid Arthritis Classification Criteria: An American College of Rheumatology/European League Against Rheumatism Collaborative Initiative. Arthritis Rheum. 2010; 62(9):2569-2581.

33. Alexiou I, Germenis A, Koutroumpas A, Theodoridou K, Sakkas LI. Anti-cyclic citrullinated peptide-2 (CCP2) and extra-articular manifestations in Greek patients with rheumatoid arthritis. Clin Rheumatol.2008;27: 511-513. DOI: 10.107/s 10067-007-0800-1.

34. Hamblin MJ, Horton MR. Rheumatoid arthritisassociated interstitial disease: diagnostic dilemma. Pulmonary medicine. 2011;1-12.DOI: 10.1155/ $2011 / 872120$
35. Chanin K, Vallejo-Manzur F, Sternbach GL, Fromm RJ, Varon J. Pulmonary manifestations of rheumatoid arthritis. Hospital Physician. 2001 July: 23-28.

36. Terasaki H, Fujimoto K, Hayabuchi N, Ogoh Y, Fukuda T, Muller NL. Respiratory symptoms in rheumatoid arthritis: Relation between high resolution CT findings and functional impairment. Radiation med. 2004; 22(3): 179-185.

37. Mori S, Koga Y, Sugimoto M. Small airway obstruction in patients with rheumatoid arthritis. Mod Rheumatol. 2001 Apr; 21(2): 164-173.DOI: 10.1007/s10165-010-0376-5.

38. Sathi N; Chikura B; Kaushik VV; Wiswell R; Dawson JK. How common is Methotrexate pneumonitis? A large prospective study investigation. Clin Rheumatol. 2012;31: 79-83. DOI: 10.1007/ S10067-011-1758-6.

39. Ohbayashi M, Kubota S, Kawase A, Kohmyama N, Koboyashi Y, Yamamoto T. Involvement of epithelial-mesenchymal transition in Methotrexate-induced Pulmonary fibrosis. J Toxicol Sci.2014; 39(2): 319-30.

40. Global Strategy for the Diagnosis, Management and Prevention of COPD, Global Initiative for Chronic Obstructive Lung Disease (GOLD) 2017. Available from: http://www.goldcopd.org/ 